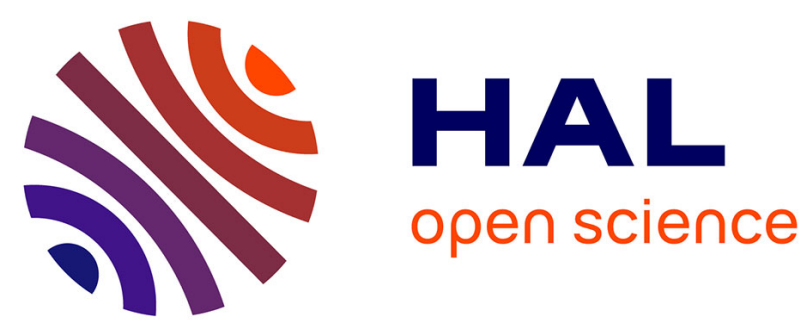

\title{
Production of Sustainable Electricity in Landfills: The Case of the Bandeirantes Landfill
}

Marise De Barros Miranda Gomes, José Benedito Sacomano, Fabio Papalardo, Alexandre Da Silva

\section{- To cite this version:}

Marise De Barros Miranda Gomes, José Benedito Sacomano, Fabio Papalardo, Alexandre Da Silva. Production of Sustainable Electricity in Landfills: The Case of the Bandeirantes Landfill. IFIP International Conference on Advances in Production Management Systems (APMS), Sep 2014, Ajaccio, France. pp.366-373, 10.1007/978-3-662-44736-9_45 . hal-01387899

\section{HAL Id: hal-01387899 \\ https://inria.hal.science/hal-01387899}

Submitted on 26 Oct 2016

HAL is a multi-disciplinary open access archive for the deposit and dissemination of scientific research documents, whether they are published or not. The documents may come from teaching and research institutions in France or abroad, or from public or private research centers.
L'archive ouverte pluridisciplinaire HAL, est destinée au dépôt et à la diffusion de documents scientifiques de niveau recherche, publiés ou non, émanant des établissements d'enseignement et de recherche français ou étrangers, des laboratoires publics ou privés.

\section{(c)(1)}

Distributed under a Creative Commons Attribution| 4.0 International License 


\title{
Production of Sustainable Electricity in Landfills: The Case of the Bandeirantes Landfill
}

\author{
Marise de Barros Miranda Gomes ${ }^{1,2}$, José Benedito Sacomano ${ }^{1}$, Fabio Papalardo ${ }^{1}$, \\ Alexandre Erdmann da Silva ${ }^{2}$ \\ ${ }^{1}$ Universidade Paulista (UNIP), Post Graduate Program in Production Engineering, Dr. Bacelar \\ St. 1212,São Paulo,Brazil \\ ${ }^{2}$ Centro Universitário das Faculdades Metropolitanas Unidas - FMU, São Paulo, São Paulo. \\ \{marise.gomes@superig.com.br\}
}

\begin{abstract}
This study shows the potential of biogas in urban solid waste landfills which, according to estimates and based on the international experience, did not show satisfactory results. The issue of solid waste in Brazil has been discussed by society over the years. Besides dealing with the issues of greenhouse gases emissions, it comprises the context of sustainability in the use of methane as a source of renewable energy. Waste landfills generate gas emissions that are harmful to people and to the environment. In Brazil, there are few projects on the use of methane energy. They are located in the south and southeast regions and some of them show technical difficulties due to failures in predicting the production of landfill gas. Specifically, the country has three projects for waste management for large-scale production of energy. Among them, there is the object of this case study, the Bandeirantes Biogas Plant in São Paulo, supported in mathematical modeling.
\end{abstract}

Keywords. Landfill, production optimization, sustainability, energy, renewable energy.

\section{Introduction}

Currently, megacities worldwide are faced with the generation of solid wastes. The result of the intense urbanization and the search for different solutions aim to mitigate the environmental damage. Many solutions are the best practices in the recovery of such wastes when disposed of in landfills. Recent concepts in modern landfill management, incorporate sustainability strategies in their lifecycle, so since the beginning of the landfill, different techniques are tested to stabilize the amount of methane gas emissions [1]. Energy recovery is one of the indicators of sustainability for landfills [2].

The methane gas produced at the landfill, depending on the waste deposited there, may have its production confined with the goal of producing electrical energy, by burning in combustion engines. 
The concept of sustainability created by the Helmholtz Institute [3], an important center of research and technology from Germany, highlights the use of energy and natural resources in an efficient, safe and sustainable way. Therefore, it defines the minimum requirements that are universally valid for the global sustainable development, unconventionally. It assigns the deficit of sustainability indicator to the forecasts of global energy shortage, to power supply or generation, to the extraction of raw materials and waste disposal without its energy recovery.

In this sense, over the years, Brazil and the world concentrate their efforts and studies on the subject that defies all: solid waste in the context of landfills [4]. In its management, an order of priority should be observed: no generation, reduction, reuse, environmentally appropriate treatment and disposal. The same author also mentions, based on German law, that unavoidable wastes must be recovered, in the form of material recovery or energy recovery.

The United Nations/ONU [5] warns, in its report, that some challenges of sustainable development of the cities up to 2050 are related to renewable energies and urban waste management. In Brazil, despite the implementation of measures of selective collection, much of the waste is not targeted for recycling, going directly to landfills and increasing environmental pollution. Among the common challenges, we must consider the specificity of the disposal practice related to the economic development.

The relation between economic development and waste generation is direct. The increased purchasing power, coupled with the population growth and the increasing consumption of disposable materials contribute to the problem of depletion of landfills and the pollution generated by the improper disposal [6].

The few projects on biogas energy use in Brazil are located in the southern and southeastern regions, but some of them show technical difficulties due to failures in predicting the production of landfill gas [7; 8]. We took Bandeirantes Landfill as a case study in order to contextualize sustainability in relation to waste disposal and energy recovery. Parameterizations were needed, from the data collected, because of the indeterminacy of the waste types and amount of moisture, for example, and of how these two indicators have been distributed over the years of the landfill existence.

\subsection{Lifecycle of a productive plant of landfill gas}

The former Bandeirantes landfill, since 2008, started to generate energy and to be named as Bandeirantes Thermal Power Plant because of the stimuli in the production of electricity and carbon credits from the burning of methane. The case study is a dynamic environment that has undergone changes throughout its production cycle, initially just as a place of accumulation of waste, and after many years, it started to generate electricity.

This study indicates that the productive lifecycle of Bandeirantes landfill is divided into 4 stages. These four stages represent the dynamics of the landfill. Over 51 years, it went from trash dump to a controlled landfill for 11 years. With an operating license it has become a landfill. From 2008, the Bandeirantes landfill began to operate as an independent producer and supplier of electricity. The expectation of this last phase is 
estimated to expire in 2030. The highest peak of sustainable productivity and methane generation was recorded in 2004, when it was still operating as a landfill.

Many research concluded that the design method estimates lower rates of methane generation, since it takes into account the average of disposition of different types of waste, leading to inaccurate results. They suggested that the method of first-order decay is more complete and that it best approximates the reality, since it takes into account the long periods of time in the emission of methane gas and the increase of waste each year, within its lifecycle as a landfill $[10 ; 11]$. The reasons given below demonstrate the motivation for using this model in the current study, in addition to the representation of the selection criteria used, which will be explained in the next section.

\section{$2 \quad$ Methodology}

\subsection{Model for estimating the production of methane gas in landfills}

The parameters of the models cannot represent the actual conditions of the landfill because they are based on experimental studies without effective measures in the field. Also, the dynamics of a landfill in relation to the disposal, the accommodation of waste, the heterogeneous accumulation of material types and the emanation of methane gas are random variables $[12 ; 13]$.

The first official calculation methodology for reducing emissions of greenhouse gases approved by the Clean Development Mechanism/CDM Executive Board is based on Intergovernmental Panel on Climate Change/IPCC [14], which was an evolution of the methodology proposed in 1996, described hereafter as a first-order decay equation.

The purpose of this equation is the functionality in the calculation and a possible implementation in computational tools, and the validation through in situ measurement of values is in the audit stage [11]. This result that the mathematical model serves as a support for predicting the generation of methane gas easy to implement in computer systems.

\subsection{Modeling parameters in the landfill methane gas production}

The decay function or exponential increase is a derivation with respect to discrete time, this means that there were differences in the time variable, for example, $\mathrm{t} 1-\mathrm{t} 2$, $\mathrm{t} 1 \mathrm{-t} 3$ and so on, to then integrate these differences and present them in graphical form. Mathematical models are often used to describe real-life phenomena or the behavior of a system [15]. The construction of a mathematical model of a system begins by identifying the variables responsible for the behavior of the system. The same author also points out that in the initial model the incorporation of all variables is not necessary because, at this stage, the desired specification is for the validation of the model and not on the resolution level required. Some variables in the first-order equation have no database, there are difficulty of finding the database in order to estimate accurately the values of Potential of methane generation and Methane generation rate [16]. 
This emission factor associated with the site of residue destination interferes with the estimated portion of generation of methane gas. Landfills have factor 1 of $100 \%$. It is estimated that these sites have adequate control regarding the handling and compaction of waste.

The controlled landfill has a $20 \%$ lower factor, due to the environmental monitoring, but it does not have the same operating and control conditions of the landfills. Lastly, the trash dump, which has no operational, management or environmental monitoring control, has its potential factor reaching only $40 \%$ of the methane generation.

In this factor, it is also applied a collection efficiency parameter that is around 60$85 \%$, depending on the impossibility of capturing all the gas generated. The total amount of waste generated is not the same amount collected and destined to landfills. In addition, a percentage of the population does not receive the services of the public waste collection system.

In this case study, the production of landfill gas is supposed to be a set of derivations of various speeds of gas production, which are not known or mastered. The speed is the kinetic involved in the equation, and it is a dependent variable of time, which relation between time and the gas kinetics, at all points of the facility, is very difficult to be determined or measured. This demonstration of the first-order equation was required so the steps to be implemented in the simulation can be followed in this subject matter. The algorithm ode45 of Matlab will be used for the integration of the dynamic system and simulation in Simulink.

By converting methane gas into thermal energy and then into electrical energy, it is possible to estimate the energy potential of Bandeirantes Thermal Power Plant, and also the equivalent carbon credits in these processes, both vital for a sustainable project. In this context, explainations about in order to calculate the emission of a certain gas, we multiply the mass emitted by this gas by the ECD (Equivalent Carbon Dioxide) or $\mathrm{CO}^{2} \mathrm{eq}$ of the aforementioned (destroyed) gas [17].

Finally, due to the price on the Carbon Market, it is possible to calculate the sales values of equivalent Credits of Carbon (CRCeq) that have been mitigated to different opportunities for energy generation and recovery of landfill gas. However, they are only tradable for projects certificated by the CDM board.

Clean Development Mechanism/CDM shows that the Certified Emission Reductions (CERs) are traded as commodities that can be bought by countries that fail to meet emissions reduction targets or that do not want the adhesion within their development plans. Each tonne of $\mathrm{CO}^{2} \mathrm{e}\left(\mathrm{tCO}^{2} \mathrm{e}\right)$ reduced or removed from the atmosphere is a unit issued by the CDM Executive Board or other voluntary markets, called Certified Emission Reductions (CERs).

The market for Carbon Credits is complex. It counts on the participation of several entities worldwide. There are conditions and goals to be achieved and agreed deadlines to be fulfilled by the involved countries, both developed countries interested in purchasing carbon credits and developing countries that want to sell by the best market price.

In summary, all parameters were defined and established to be used in the simulation. We sought, in previous studies, to justify the parameters involved and possible flexibilities that are the setting for the simulation. Carbon credits are processed 
only for simulation purposes in quantity and sales value in the market, representing only a positive output of the system.

\section{$3 \quad$ Results and Discussion}

\subsection{Modeling of sustainable electricity production in the Bandeirantes landfill}

In this modeling of the sustainable production of electricity, the Bandeirantes landfill is named as Thermal Power Plant. In its initial design, it aimed to turn methane gas into energy and to recover carbon credits. Figure 1 shows the stages in this process. Each process uses the baselines recommended by the Executive Board of the CDM, established in the ACM0001 methodology, in order to simulate large-scale projects. These practices contribute to the research on the applicability of methodologies in different scenarios, especially for the developing countries to establish sustainable development paths.

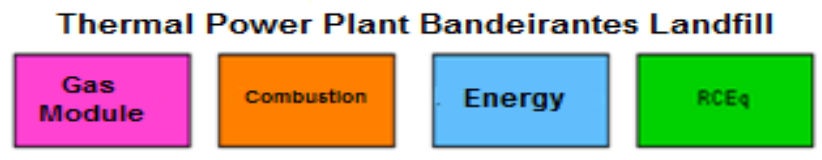

Fig. 1.Stages of the Bandeirantes Thermal Power Plant process

For each stage, there is a mathematical model that represents the estimates. The initial phase, called gas module by the author, is a composition of matrices, and so each stage is composed of a mathematical modeling.

From these arrangements, there are steps which are composed of other equations. For simulation purposes, each step is a process or system, which may have derivative subprocesses or subsystems. The Gas Module stage was modeled in Matlab and Simulink, and the others, since they were only calculations, were aided by Matlab's Toolbox. To accomplish this calculation, the adaptive Simulink module was used with data input of matrices. Three composite inputs were necessary to form the three geometric axes. Next, Figure 2 shows the partial simulation scheme for two input matrices $(\mathrm{x}, \mathrm{y})$.

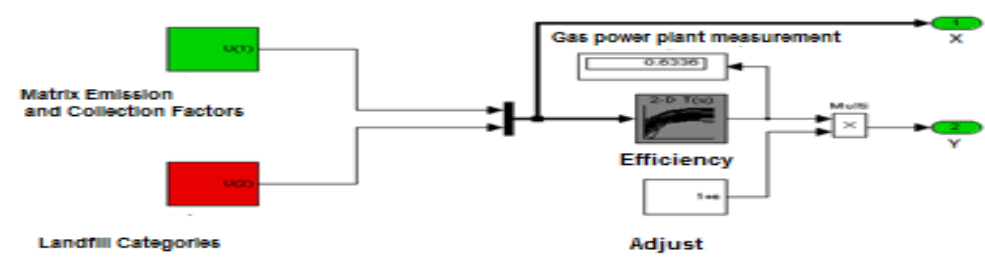

Fig. 2. Gas Module Simulator (partial) - 2 input matrices

The tool limitation prevents the construction of a three-dimensional chart. The volumetric module in Simulink library is a 2-D T(u) module (two-dimensional module). To solve this problem, two other modules were constructed for vector outputs $(\mathrm{X}, \mathrm{Z})$ 
and $(\mathrm{Y}, \mathrm{Z})$. At the output of the three matrices, an adaptive module was included to determine L0 throughout the production cycle.

In the simulation shown in chart following, the three categories were divided into 1 for landfill, 2 for controlled landfill and 3 to trash dump. The last one had the lowest result regarding the Potential of methane generation variable. The blue bar was coded for the results of $60 \%$ collection percentage and the red bar to $85 \%$ performed collection. The potential of methane generation had the following results in the simulation compiled, from the reading of chart 1 .

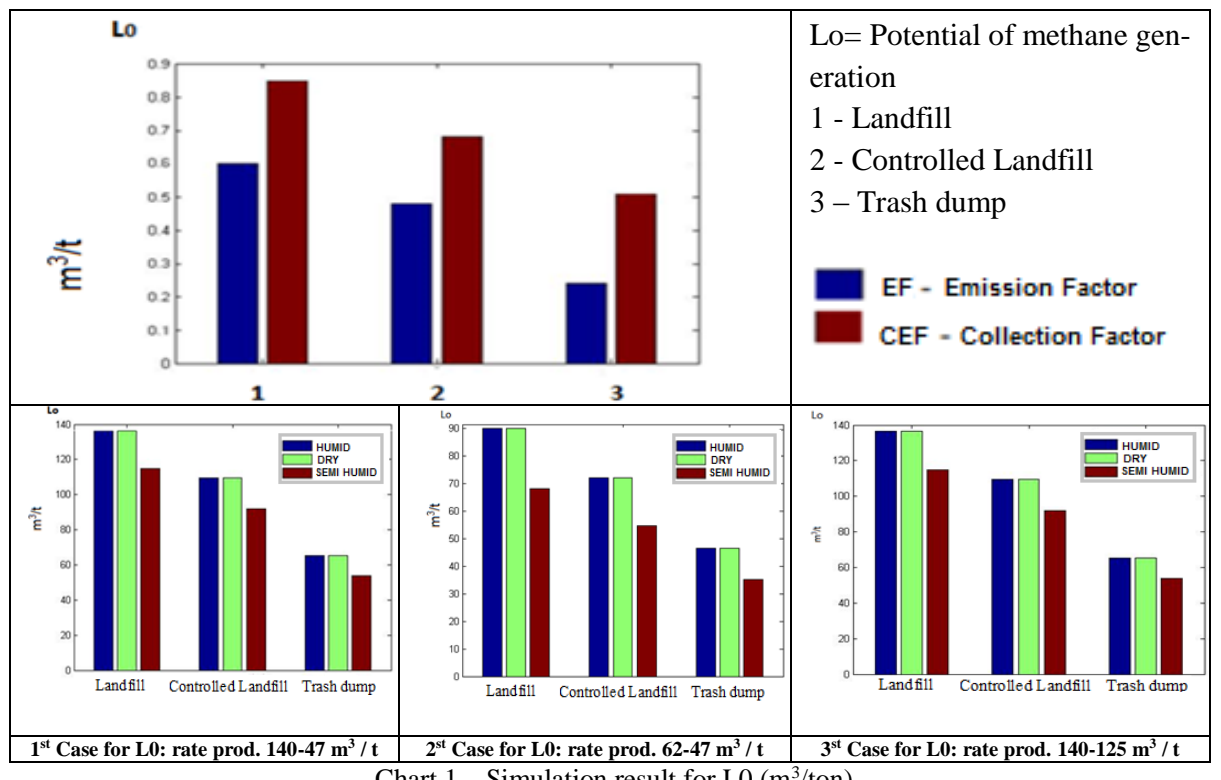

Chart $1-$ Simulation result for $\mathrm{LO}\left(\mathrm{m}^{3} /\right.$ ton $)$

The simulation of this scenario shows, in chart 1, that there was an improvement in the performance of methane gas generation in all sites of waste disposal, even more at the dump. The two locations of inappropriate disposal had their emissions increased. The simulation was repeated, by changing the vector order of the matrix elements. The result was exactly the same, proving that the result of the first simulation was correct, thus confirming the increase in methane generation in plants considered inadequate, but with the amount of gas production that is not used.

The performance in humid and dry climates improves gas production and affects it in semi-humid climate according to the result of chart 1 . Although it has adopted the worst values for methane production, the performance to landfill improved in the 2nd case when compared with the 1 st case.

The humid and dry climates positively affect the production of gas in the controlled landfill, staying above the result influenced by semi-humid climate in the landfill.

In 3nd case, the results show a balanced performance. The semi-humid climate improves gas production in the landfill staying above the gas production in controlled landfill and landfill influenced by the three climates. The current Bandeirantes Thermal 
Power Plant was initially a trash dump, evolving to a controlled landfill and then to landfill, which was closed in 2006. This three-stage production cycle generated a volume of methane gas with potential for energy recovery.

\section{Conclusions}

This study shows that the current methods do not simulate optimal conditions or minimum conditions. They work with data directed to the future when the project goes into operation as a plant, and they do not consider methane potential in the production cycle, discarding energy production since the establishment of the plant. In this scenario, the plant did not value 2,095,724,529 $\mathrm{m}^{3}$ of GHG; this corresponds to the production of 2,356,207 MWh. It would be possible to fuel the plant and still have 2,244,175 MWh.

The simulation shows that by 2030 , the plant will produce $1,424,148,778 \mathrm{~m} 3$ of GHG. This is equivalent to the generation of $1,683,183 \mathrm{MWh}$, and subtracting the cost of energy, from 2008 to 2030, it could inject 1,552.479 MWh in the electrical grid of São Paulo. In the estimate of carbon reduction they could only be "commercialized" from 2010, referring to the latest contract approved by the CDM. There is the estimate that by 2017 , when the contract will be terminating, $1,751,497 \mathrm{tCO}^{2} \mathrm{e} /$ year will be commercialized.

The number of controlled landfills, trash dumps and landfills that are not recovering the methane as energy and carbon credits deserves to be evaluated. Producing energy and, on the other hand, trading carbon credits on the market as a commodity of energy production can be a good investment. The issue of controlled landfills, landfills or trash dumps undergoes a recent great transformation. With the goal closing the landfills up to 2014 , there should be a huge incentive to the recycling and reuse of materials. However, as well as in Germany, although it is mature regarding waste disposal processes, landfills will continue to exist.

Several readings can be completed in this study. Brazil needs to review its security policies and maintenance of the energy matrix. In the case studied, the former Bandeirantes landfill, São Paulo, did not add the amount of 1.5 Tera Watts/hour to its power grid in little more than 20 years. More than that, it lost more than $1.5 \mathrm{TWh}$ of energy. Somehow, this process of Bandeirantes Thermal Power Plant did not efficiently contribute to the environment. If we consider the period that it did not use GHGs, in this case methane, Bandeirantes Thermal Power Plant could have been better utilized in terms of energy source if it had been rethought in its entire production cycle.

\section{$5 \quad$ References}

1. Hrad, M., Gamperling, M. Huber-Humer, M. Comparison between lab- all full-scale applications of in situ aeration of an old landfill and assessment of long-term emission development after completion. Waste Management 33 (2013), 2061-2073 p. 
2. Martinez, T. G., et al. The potential of a sustainable municipal waste management system for Santiago de Chile, including energy production from waste. Energy, Sustainability and Society, Volume 2, 2012.

3. Helmholtz Association og German Research Centres. Helmholtz - With Enregy into the Future. Annual Report. Berlim, 2010.

4. Jardim, A.; Yoshida, C.; Machado, F. J. V. Política Nacional, Gestão e Gerenciamento de Resíduos Sólidos. Editora Manole, Barueri, SP, 2012. Pág 19, 34 à 36, 62 e 63.

5. ONU - United Nations. Sustainable Development Challenges. World Economic and Social Survey. Department of Economic and Social Affairs, UN, N. ew York, 2013. 181 p, page 68.

6. Dias, S. G. O desafio da Gestão de Resíduos Sólidos Urbanos. Sociedade e Gestão. Revista RAE, Fundação Getúlio Vargas, 16 vol. 11 nº 1 jan/jun 2012.

7. Maciel, F. J.; Jucá, J. F. T. e Neto, A. C. Avaliação do Projeto Piloto de Recuperação do Biogás no Aterro da Muribeca/PE. VI Congresso de Inovação Tecnológica em Energia Elétrica, Anais, Fortaleza, Ce, 2011. 8 p, pág 1.

8. MMA - Ministério do Meio Ambiente. Agenda 21 brasileira: resultado da consulta nacional / Comissão de Políticas de Desenvolvimento Sustentável e da Agenda 21 Nacional. 2. ed. Brasília : Ministério do Meio Ambiente, 2004, 158 p, 93.

9. Mendes, L. G. G.; Magalhães, S. P. Estimate Methods of Biogas Generation in sanitary landfill. Universidade Estadual Paulista - UNESP. Faculdade de Engenharia, Campus Guaratinguetá - FEG. Departamento de Energia - DEN. Rev. ciênc. exatas, Taubaté, v. 11, n. 2, p. 71-76, 2005.

10. Gomes, M. B. Sustentabilidade Ambiental no Brasil: biodiversidade, economia e bem-estar humano. Comunicados do IPEA (instituto de Pesquisa Aplicada) no 80. Série Eixos do Desenvolvimento Brasileiro. Edição de fevereiro, 2011. 27 p, pág10 a 17.

11. USEPA - Environmental Protection Agency. United States International Best Practices Guide for Landfill Gas energy Projects. Landfill Gas Modeling. Global Methane Iniciative. Capítulo 6, 2012, 14p, pág $63-67$.

12. Christensen, H. T. Journal of Solid Waste Technology and Management. Volume $1 \& 2$. Wiley, 2010, capítulo 2.1. Waste Characterization: Approaches and Methods, pág 61-84.

13. Worrell, W. A. e Vesilind, P. A. Solid Waste Engineering. $2^{\text {a }}$ Ed, Cengage Learning, 2011. 401 p, pág 118 e 119.

14. IPCC - Intergovernmental Panel on Climate Change. Guidelines for National Greenhouse Gas Inventories. 1997. Disponível em: http://www.ipcc-nggip.iges.or.jp/public/gl/invs6.html>. Acessado em: 29 maio 2012.

15. Anton, H. et al. Cálculo. Volume I. Bookman, $8^{\mathrm{a}}$ Ed.Porto Alegre, 2005. Capítulo 9, 1181p, pág 582-611.

16. ABRELPE. Atlas Brasileiro de emissões de GEE e Potencial Energético na Destinação de Resíduos Sólidos. Abrelpe - Associação Brasileira de Empresas de Limpeza Pública e Resíduos Especiais. Diretor Executivo: Carlos R. V. Silva Filho, 2012, 172p.

17. Taboada, C. Gestão de Tecnologia e Inovação na Logística. Iesd Brasil SA. Curitiba, 2009, 104 p, pág $80-85$. 